\title{
Os Sofrimentos da Alma: As Paixões sob a Perspectiva do Estoicismo
}

\author{
The sufferings of the Soul: \\ The passions under the Stoicism perspective
}

Diogo da Luz
Mestre em Filosofia pela Pontifícia Universidade Católica do
Rio Grande do Sul (PUCRS)

Resumo: Neste artigo exploramos a concepção estoica de $\pi a ́ \theta o s$, suas causas e consequências. Inicialmente abordamos o modo como as paixões se encaixam na ética estoica, uma vez que elas se mostram como impedimentos para aquele que quer viver melhor. Logo depois, analisamos os debates realizados no seio da escola, os acréscimos e os aperfeiçoamentos teóricos. Por fim, mostramos a distinção

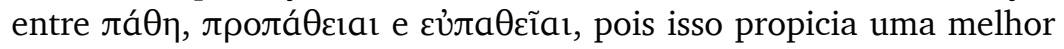
compreensão da dimensão emocional da psicologia da Stoa, servindo principalmente para evitar interpretações precipitadas que podem ocorrer ao se ler um texto estoico.

Palavras-chave: Estoicos; Paixões; Pathos; ПáӨos; Emoções.

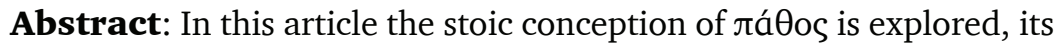
causes and consequences. Initially, it is approached how passions fit Stoic ethics, since they appear as impediments to those who want to live better. Afterwards the debates within this school are analyzed, its 
additions and the theoretical improvements. Finally, the distinction

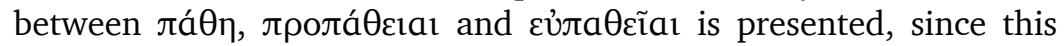
provides a better understanding of the emotional dimension of Stoa's psychology, mainly to avoid precipitous interpretations that may occur when reading a Stoic text.

Key-words: Stoics; Passions; Pathos; ПáӨos; Emotions.

\section{Introdução}

O estoicismo perdurou por um considerável tempo na antiguidade. Devido a essa extensão temporal, ele foi dividido em três fases: antigo, médio e imperial. O principais representantes do período antigo são Zenão, Cleantes e Crisipo, que conduziram a escola ainda em Atenas. Posteriormente, para além dos limites atenienses, Panécio e Possidônio se destacaram na continuidade dos ensinamentos, sendo responsáveis também por uma espécie de sincretismo filosófico (Sedley, 2006, p. 21-26). Por fim, à época do império romano, podemos destacar alguns nomes como Sêneca, Epicteto e Marco Aurélio.

No que se refere à doutrina, um dos aspectos mais relevantes, que perpassou todas essas fases, foi a questão da busca por uma vida boa, sábia - nomeadamente a parte ética da doutrina. De acordo com os estoicos, a vida boa é aquela que se conecta plenamente ao momento, ao acontecimento (Deleuze, 2011, p. 149), é a que se concretiza naquele que consegue se compatibilizar devidamente ao fluxo das coisas; é a que não precisa de algo a mais para ser feliz, pois nada a insatisfaz; é a que não se frustra com o que ocorre, porque consciente de que é o estado de espírito perante as situações que realmente importa na consideração de quão sabiamente se vive.

Para alcançar a fortaleza da pessoa sábia perante as oscilações da fortuna é preciso reagir de forma correta ao que se apresenta. Isso ocorre por meio do assentimento correto às representações, visto que estas intermedeiam a nossa relação 
com o mundo (Acad., I, 40-42 ${ }^{1}$ ). No entanto, é importante ressaltar que a habilidade nas representações não se confunde com uma habilidade genérica ou superficial no seu manuseio (como ocorre na sofística), mas à aplicação correta e constante de bons assentimentos de maneira a firmar e estabilizar uma disposição, tornando-a virtuosa (Boeri, 2007, p. 311-312).

Sendo assim, após essa breve introdução, passemos então à consideração das paixões.

\section{ПáӨos e Erro}

Segundo Diógenes Laércio, Zenão, o fundador do estoicismo, afirmou que o fim supremo da vida humana é viver em conformidade com a virtude (ảpecń), sendo isso também o mesmo que viver em conformidade com a natureza. Crisipo, por sua vez, ampliou essa concepção e afirmou que viver segundo a virtude "coincide com viver de acordo com a experiência dos fatos da natureza, e que nossas naturezas individuais são partes da natureza universal" (DL, VII, 87). Nesse caso, ao fazer essas modificações, Crisipo chamou a atenção tanto para a relação entre natureza e acontecimento quanto para a perspectiva das naturezas particulares (ỉía), divergindo também da ideia de Cleantes de entender "que devemos seguir somente a [natureza] universal, e não a individual” (DL, VII, 89).

As ações em conformidade com a natureza são chama-

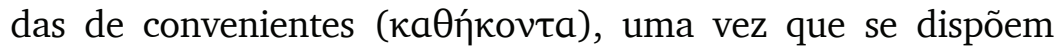
harmonicamente junto à medida natural ( $\sigma u ́ \mu \mu \varepsilon \tau \rho o \varsigma)$. Essas são as ações consideradas devidas ${ }^{2}$, dado que expressam o que

\footnotetext{
1 Abreviaturas - Acad.: Cícero, Academicas / Disp. Tusc.: Cícero, Discussões Tusculanas / DL: Diôgenes Laêrtios. Vidas e doutrinas dos filósofos ilustres / SVF: Arnim, Stoicorum Veterum Fragmenta / Ep.: Sêneca, Cartas a Lucílio.

2 Nesse sentido, a ideia estoica de dever se mostra diferente da noção kantiana, dado que para os estoicos o dever é seguir a natureza ao passo que para o segundo o dever é seguir um imperativo que constrange a natureza. De acordo com Kant: "Os impulsos da natureza, assim, contêm obstáculos à realização do dever no ânimo do ser humano e forças (em parte poderosas) que opõem resistência, as quais ele tem de julgar-se capaz de combater e, por meio da razão, vencer, não apenas futuramente, mas sim imediatamente (em
} 
se espera de uma conduta humana que está em sintonia com a natureza. Do contrário, quando as ações não são convenientes, produz-se uma divergência que evidencia um problema na forma como se vive. De acordo com a linguagem estoica, uma vida desmedida, ou fora da medida, é aquela cujos impulsos (ó $\rho \mu a i ́)$ não estão em conformidade, produzindo uma desarmonia entre sujeito e natureza. O preço dessa desarmonia é justamente não conseguir lidar bem com as coisas/fatos, causando problemas na forma de se relacionar com elas/eles. Dessa forma surgem os medos, as ansiedades, as preocupações, em suma: as paixões ( $(a ́ \theta \eta)$. Assim, a partir dessa compreensão inicial acerca da relação entre paixões e impulso desmedido, podemos compreender porque alguns estoicos conceberam as paixões também como impulsos excessivos. Conforme relata Galeno:

Contudo, também foi mencionado o excesso de impulso, porque excede a medida dos impulsos, inclusive a que é natural, que concorda consigo mesma. O que se disse se tornaria mais compreensível através do seguinte: por exemplo, quando uma pessoa caminha de acordo com o impulso, o movimento de suas pernas não é excessivo, mas, em certo modo, comensurável com o impulso, de modo que se pode tanto deter quando o caminhante o desejar quanto mudar de direção. Mas no caso dos que correm de acordo com o impulso já não se produz algo da índole indicada, pois o movimento das pernas é a tal ponto excessivo com relação ao impulso que os corredores são arrastados, não podem mudar de direção nem obedecer [a razão] logo que as pernas começam a se mover. Creio que algo semelhante a esses [movimentos] também ocorre com os impulsos devido a um excesso na medida racional, de modo que quando um corredor se impulsiona, não obedece à razão. E enquanto o excesso de movimento é chamado "contrário ao impulso", o excesso de impulso é chamado "contrário à razão". Com efeito, a medida natural do impulso é a que está em conformidade com a razão, e é do tamanho que a razão considera adequada. Portanto, também resulta óbvio que quando o excesso surge nesse sentido e desse modo, diz-se que o impulso não só é excessivo, mas também contrário à natureza, ou seja, é um movimento irracional da alma. (SVF, III, 462)

Como se pode perceber, além de serem impulsos excessivos, as paixões também são concebidas como movimentos ir-

simultâneo com o pensamento), a saber, poder fazer aquilo que a lei ordena incondicionalmente que ele deve fazer." (Kant, 2013, p. 381). 
racionais da alma. Como relata Inwood, Crisipo entende que esses impulsos excessivos ocorrem para além da razão parti-

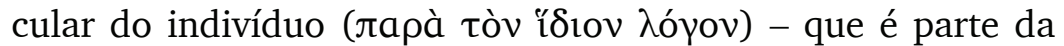
razão divina (1985, p. 160). Assim sendo, pode-se identificar que outra característica das paixões é sua irracionalidade. Porém, é necessário entender que essa irracionalidade não implica ausência de elaboração racional; na verdade, ela implica uma desobediência à razão (SVF, III, 378; 389), pois o uso da razão é algo que já faz parte da condição humana (Crisipo de Solos, 2006, p. 195). Isso reflete o que se denomina de monismo psicológico dos estoicos, visto que a racionalidade não se ausenta nem se suprime em detrimento de outras faculdades irracionais. Nesse aspecto, os estoicos gregos são radicalmente diferentes de Platão e Aristóteles, pois não dividem a alma em partes racionais e irracionais. Platão, porque divide a alma em duas partes irracionais e uma racional (Rep., Livro IV), defende que a parte racional deve subjugar as outras duas para que as paixões não se estabeleçam e acabem por desviar o ser humano do caminho virtuoso. A divisão da alma nas partes apetitiva, irascível (impetuosa) e racional (

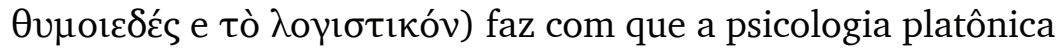
dependa da consideração de partes distintas, diferenciando-se da perspectiva monista estoica ${ }^{3}$. Aristóteles, por sua vez, também divide a alma, mas em duas partes: racional e irracional

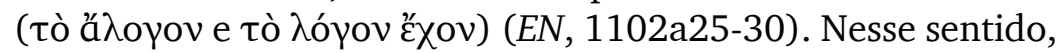
Aristóteles também diverge da psicologia estoica, pois, assim como Platão, sustenta uma psicologia fragmentada.

De acordo com a psicologia estoica, a racionalidade afeta o sujeito de forma integral, servindo como artesã do impulso

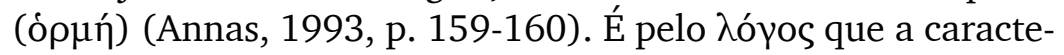
rística propriamente humana se revela, pois os demais animais, apesar de serem capazes de lidar com representações (Boeri, 2007, p. 308), não escolhem o que pensam ser o melhor em função das noções de bem e de mal. É por isso que os animais não erram eticamente ao fazer escolhas, mas os seres humanos

3 Devido à influência que a filosofia platônica exerceu no estoicismo médio, é possível identificar uma exceção na psicologia de Possidônio, como veremos mais adiante. 
sim. O errar humano, nesse sentido, é um errar o alvo, e esse alvo é entendido como aquilo que se reputa como um bem. $\mathrm{O}$

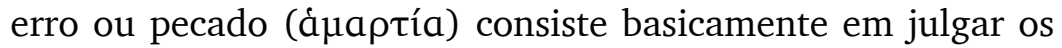
bens aparentes como bens verdadeiros (Boeri, 2007, p. 283313). Essa confusão entre bens verdadeiros e bens que aparentam ser verdadeiros está no núcleo daquilo que se relaciona ao intelectualismo da psicologia estoica. Influenciados pelas ideias de Sócrates, os filósofos do pórtico entendem que o erro está na origem dos males, ou até mesmo o concebem como o próprio mal. Os problemas, os sofrimentos, os padecimentos e as perturbações dos seres humanos ocorrem em função de equívocos,

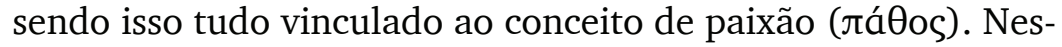
se sentido, as paixões são impulsos errôneos da alma, pois se projetam em função de irracionalidades.

Para explorar melhor a noção de đáӨoৎ no estoicismo, podemos nos servir de uma descrição de Estobeu. Segundo ele, os estoicos definiram quatro paixões principais às quais todas as demais estão associadas: apetite, medo, prazer e dor:

Afirmam [os estoicos] que uma paixão é um impulso excessivo e desobediente à razão seletiva ou um movimento <irracional $>$ da alma que é contrário à natureza - todas as paixões pertencem ao

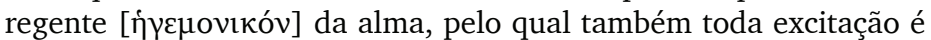
paixão e, por sua vez, toda paixão é excitação. Posto que a paixão é de tal índole, deve-se supor que enquanto umas paixões são primárias e fundantes, outras, por sua vez, se referem a estas. Primárias em gênero são estas quatro: apetite, medo, dor e prazer. Apetite e medo vêm primeiro, aquele com relação ao que se mostra como bom, este com relação ao que se mostra como mau. Prazer e dor, por sua parte, sobrevêm ao apetite e ao medo: prazer por toda vez que conseguimos aquilo pelo que tínhamos apetite ou por toda vez que evitamos aquilo que temíamos. Dor, por sua parte, toda vez que não conseguimos o que desejávamos ou toda vez que nos encontramos com o que temíamos. Mas no caso de todas as paixões da alma, quando dizem que são opiniões, adotam [a expressão] 'opinião' em vez de 'suposição débil' e 'vivaz' em vez de '[fator] motor de uma contração ou uma expansão irracional'. (SVF, III, 378; 389)

Podemos notar que, dentre as paixões fundantes (ou primárias em gênero), o apetite e o medo são descritos como condições para as paixões supervenientes de prazer e dor. Ou 
seja, prazer e dor surgem em função já de condições passionais, mas com a diferença de que precisam de um assentimento diferente que relaciona o conteúdo passional ao momento presente. Tomemos como exemplo uma pessoa que julga a riqueza material um bem: se ela é de fato rica, então seu apetite se manifesta no desejo de manter ou aumentar a riqueza e seu medo no receio de perdê-la ou diminuí-la. Como ela tem a riqueza em alta estima, acaba ficando intranquila sempre ao visualizar essas situações. Além disso, ela também sente prazer ao usufruir de sua riqueza, assim como lhe é penoso (dor) se tal não se fizer presente.

Segundo Diógenes Laércio (VII, 111-114), das paixões fundantes (primárias em gênero), podemos extrair todas as demais, conforme os quadros a seguir:

\begin{tabular}{|c|c|}
\hline $\begin{array}{l}\text { Apetite } \\
\dot{\varepsilon} \pi \imath \theta u \mu i ́ a\end{array}$ & $\begin{array}{l}\text { Insatisfação, ódio, ambição, ira, desejo erótico, } \\
\text { cólera, ressentimento. }\end{array}$ \\
\hline $\begin{array}{l}\text { Medo } \\
\text { фóßos }\end{array}$ & $\begin{array}{l}\text { Terror, excitação, vergonha, consternação, pâni- } \\
\text { co, angústia. }\end{array}$ \\
\hline $\begin{array}{l}\text { Prazer } \\
\dot{\eta} \delta \text { ovฑं }\end{array}$ & Deleite, efusão, gozo cruel \\
\hline $\begin{array}{c}\text { Dor } \\
\lambda u ́ \pi \eta\end{array}$ & $\begin{array}{l}\text { Compaixão, inveja, ciúmes, rivalidade, aflição, } \\
\text { melancolia, inquietação, tristeza, desvario. }\end{array}$ \\
\hline
\end{tabular}

Ainda de acordo com o exemplo da riqueza, note-se que as paixões da referida pessoa ocorrem em função de uma opinião errônea acerca da riqueza. Enquanto ela entender que isso é um bem, sua alma continuará perturbada e sujeita aos mais diversos sofrimentos. Por isso, os estoicos dizem que a riqueza deve ser considerada um indiferente (ảoı́ápos), pois ela não deve fazer diferença para aquele que busca viver virtuosamente, para aquele que não aceita ser escravo de bens materiais ou de artigos de luxo. A riqueza pode no máximo ser julgada um indiferente preferível, pois, quando bem utilizada, pode ser aproveitada na promoção da vida. Por outro lado, a carência de 
bens materiais pode ser considerada um indiferente não-preferí$v e l$, uma vez que pode prejudicar no suprimento das necessidades básicas do ser humano.

Porém, mesmo com essas nuances, é importante perceber que os indiferentes (como a riqueza, a saúde, o status, etc.) não são capazes de tornar uma vida boa ou má, pois isso só pode ocorrer por meio da virtude (ou falta de virtude). Nesse sentido, o sábio - figura de referência para os ensinamentos estoicos - é aquele que possui as virtudes necessárias para lidar bem com qualquer situação que a sorte (fortuna) lhe proporcionar (Long, 1984, p. 189-191).

\section{ПáӨos, Juízo e Impulso}

Segundo conta-nos o médico e filósofo Galeno, Crisipo define as paixões de forma diferente do fundador estoicismo, Zenão. Por relacionar as paixões aos juízos, Crisipo teria se distanciado da ideia inicial do pórtico de defini-las como contrações ou expansões irracionais da alma que ocorrem em função de juízos (SVF, I, 209). Richard Sorabji (2000, p. 34-35), em sua obra Emotion and Peace of Mind, reascendeu esse debate ao afirmar que a identificação das paixões com juízos partiu de uma iniciativa própria de Crisipo, uma vez que Zenão teria relacionado as paixões aos movimentos de expansão e contração da alma, e não a juízos. Por outro lado, segundo Brad Inwood (1985, p. 129), essa diferença desaparece quando se analisa as paixões pelo viés do impulso racional, onde movimento e juízo se mostram imbricados. Essa perspectiva talvez fique mais clara se analisarmos a paixões sob o prisma de uma teoria da ação racional, que é própria aos seres humanos adultos.

Para os estoicos, o impulso se torna uma atividade racional no ser humano. Salienta-se, contudo, que as crianças, por estarem ainda em desenvolvimento, não possuem a capacidade racional totalmente estabelecida. É somente aos catorze anos de idade que a razão completa seu desenvolvimento, possibilitando, a partir de então, a madura imbricação racional

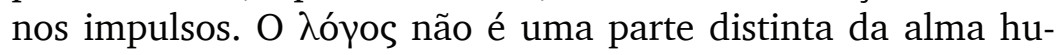


mana que pode subjugar as potências irracionais: o 入óyos já está no impulso. E o impulso, por sua vez, não é um elemento irracional que será submetido ao crivo da razão: ele já é racional ${ }^{4}$. Como diz Tad Brennan (2010, p. 93), "impulsos não são o tipo de coisa que podemos suprimir; quando nós dizemos que suprimimos um impulso, eles [os estoicos] diriam que nosso estado mental jamais chegou à condição de um impulso". Dessa forma, ao considerar as paixões como atividades racionais que envolvem impulsos, é possível assinalar que Crisipo não tenha se distanciado tanto assim das ideias de Zenão. Pelo contrário, como defende Inwood, talvez Crisipo tenha feito um refinamento na teoria estoica para ressaltar o aspecto da responsabilidade humana sobre seus próprios estados passionais (1985, p. 129). Nesse sentido, os erros nos juízos já são eles mesmos indicadores de um estado mental passional. Por isso, o nosso bem-estar psíquico é algo que nós mesmos temos o poder de promover, uma vez que chegamos a ele por meio da correção de nossas opiniões acerca do que nos ocorre. As nossas opiniões são coisas que dependem de nós. É nesse sentido que Cícero, ao descrever a relação entre opinião e paixões no estoicismo, afirma que os estados passionais são coisas que estão sob nosso poder (in nostra potestate) (Tusc. Disp., 4, 14).

Por relacionar as paixões às opiniões, o estoicismo es-

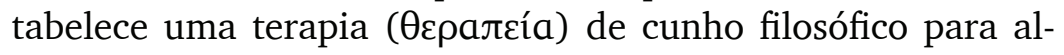

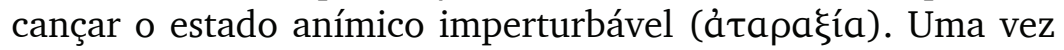
que as paixões/opiniões estão sob nosso poder, está sob nossa responsabilidade o nosso próprio bem-estar.

As opiniões, passionais ou não, efetuam-se por meio de

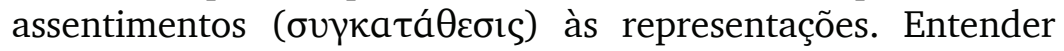
que a morte é um mal, por exemplo, é assentir à representação "a morte é um mal". Nesse sentido, todo aquele que tem essa opinião sobre a morte, em uma ocasião de perigo de vida, não conseguirá encarar a situação de forma sensata, mostrando-se perturbado. Por outro lado, se ele perceber que a morte é algo

\footnotetext{
$4 \quad$ É importante salientar que, embora existam movimentos involuntários, eles não podem ser tomados sob a perspectiva de uma atividade propriamente ética, pelo contrário, eles estão alheios a esse âmbito, como veremos mais adiante.
} 
natural à condição humana, que naturalmente ninguém vive para sempre, então conseguirá encarar a situação de perigo de forma equilibrada, da mesma forma como um sábio faria. Para assentir de forma correta é preciso entender a natureza e alinhar as opiniões àquilo que é natural.

\section{As Inovações Teóricas do Estoicismo Médio}

No estoicismo médio podemos encontrar inovações na terapia das paixões assim como algumas concepções diferentes sobre como elas se formavam. Panécio, por exemplo, estabeleceu um novo método de abordagem para os problemas passionais: ele passou a pensar o tratamento das paixões dentro do contexto atual daquele que sofre, e não sob a perspectiva do modelo ideal do sábio (Ep., 116, 5-7) ${ }^{5}$. Nesse sentido, o papel daquele que está progredindo nos ensinamentos estoicos

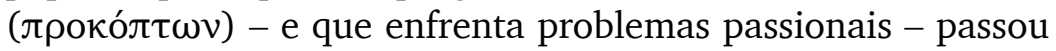
a ter grande importância. Com isso também se distinguiram as condutas apropriadas do sábio e do não-sábio, estabelecendo uma inovação na tradição estoica (Sedley, 2006, p. 25). Além do mais, a opinião de Panécio era a de que as paixões não podem ser erradicadas totalmente (Rist, 1995, p. 205), tendo inclusive rejeitado o ideal de ảđáӨcıa (Noites Áticas, XII, 5). Possivelmente essa perspectiva do filósofo estava relacionada à sua teoria das quatro personagens (personae), por meio da qual ele defendeu haver características gerais e específicas em cada indivíduo que acabam balizando a própria vida 6 . Por exemplo, Panécio não procurou conciliar as características específicas do

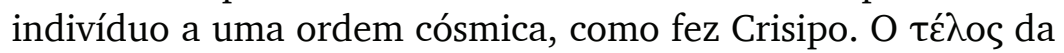
vida para Panécio está voltado para aquilo que nos é dado, ou

\footnotetext{
$5 \quad$ Para mais detalhes: Rist, 1995, p. 197.

6 De acordo com essa teoria, cada indivíduo possui quatro máscaras ou personagens, sendo duas atribuídas pela natureza, uma pelo acaso ou pelas circunstâncias e outra por nós mesmos. Das naturais, a primeira mostra a nossa condição humana genérica, ou seja, a nossa humanidade, e a segunda evidencia a nossa individualidade. A persona do acaso ou das circunstancias é estabelecida pelos papéis sociais, pelos cargos e pelas condições de status. A última é a persona estabelecida pela nossa vontade, por aquilo que acreditamos que é devido fazer. (Rist, 1995, p. 197)
} 
seja, para a nossa própria natureza (Rist, 1995, p. 196). Dessa forma, a capacidade de ter uma vida em conformidade com as próprias características parece ter sido considerada mais re-

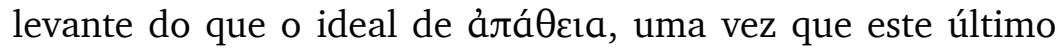
ocorre em função da perfeita disponibilidade com relação aos acontecimentos que a ordem cósmica impõe.

De certa forma, Possidônio (discípulo de Panécio) também preferiu enfatizar a educação das paixões sem vislumbrar uma forma de erradicá-las. Sua perspectiva acerca dos movimentos passionais apresentou importantes diferenças da versão mais propagada no estoicismo, ou seja, a de Crisipo. Possidônio apresentou uma teoria alternativa que questionou a forma como ocorrem os erros sintomáticos das paixões. Dado

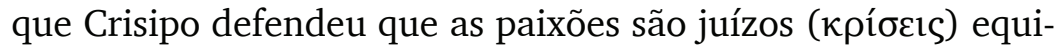
vocados, ou seja, que esses juízos já são eles mesmos impulsos passionais, Possidônio, por sua vez, questionou como apenas erros judicativos podem levar às paixões. Para Possidônio, a alma possui mais outras duas potências além da racional que são responsáveis pelos impulsos humanos: a irascível e a ape-

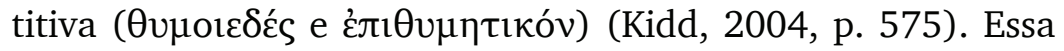
divisão é semelhante à proposta platônica, mas com a diferença de que essas faculdades não são partes da alma, mas potências que atuam como forças naturais. Por causa disso, o médico Galeno - principal fonte para a compreensão da teoria de Possidônio - entendeu que essa querela com Crisipo ocorreu em função de uma dicotomia entre racional versus irracional, por meio da qual Possidônio teria retomado a psicologia em moldes platônicos. Contudo, essa interpretação de Galeno tem sido questionada. John M. Cooper (1999, p. 449-484), em seu livro Reason and Emotion, afirmou que por Possidônio não dividir

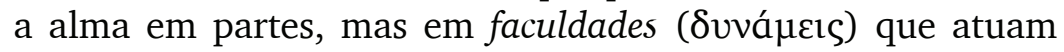
como forças naturais de apropriação - em conformidade com a teoria estoica da oỉkcíwoıs (familiaridade/apropriação/afinidade) -, fez com que tal iniciativa não acabasse contradizendo a importância da psicologia racional característica da escola estoica. Uma vez que esses movimentos irracionais não são ainda paixões, mas forças da alma, isso não implicaria uma profunda modificação na psicologia nem na terapêutica do estoicismo. 
De forma semelhante, Suzane Husson (2013, p. 145-146) também não entende a teoria de Possidônio como uma dissidência dentro da doutrina, mas apenas que ele contribuiu com uma perspectiva mais abrangente na educação dos impulsos, tanto na infância, quando a razão ainda não está totalmente formada, quanto no estágio adulto, quando a razão já se encontra desenvolvida e cumpre seu papel hegemônico.

Por outro lado, ainda de acordo com Husson (2013, p. 146), essa ponderação de Possidônio sobre a influência de fatores irracionais nas paixões teria aberto possibilidades para outras abordagens terapêuticas. Nesse sentido teria seguido Sêneca ao incluir, dentre outros, música e regime alimentar como subsídios para a terapêutica das paixões. No entanto, como observa Teun Tieleman (2003, p. 112-113, 162-166 e 194) em Chrysippus' On affections, Crisipo parece já ter atentado para a importância do regime alimentar e de outros fatores para o condicionamento da alma, uma vez que isso influencia no fortalecimento da mesma para o enfrentamento com as paixões ${ }^{7}$.

Ainda assim, torna-se relevante perceber que essas diferentes abordagens dentro da doutrina estoica não necessariamente demonstram algum tipo de "evolução teórica". Pelo contrário, o estoicismo foi um movimento que se alimentou das diversas contribuições de seus filósofos em épocas e contextos diversos. Durante o período imperial romano, Epicteto, por exemplo, retoma basicamente as contribuições dos estoicos de Atenas (Zenão, Cleantes e Crisipo), porém abordando o proble-

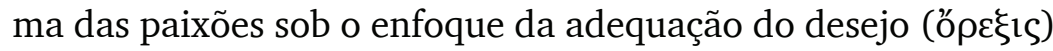
ao destino. De acordo com as Diatribes de Epicteto:

Deles [os três тóлo - desejo, impulso e assentimento] o mais importante e o mais premente é o relativo às paixões. Pois a paixão não surge de outro modo senão ao ter o desejo frustrado ou ao se deparar com o que se aborrece. Esse é o que carrega inquietudes, distúrbios, percalços, infortúnios, desgraças, padecimentos, lamentos, invejas; o que produz invejas e ciúmes, coisas pelas quais nem sequer somos capazes de escutar a razão. (Diatribes, III, 2, 3)

$7 \quad$ Somos gratos ao prof. Aldo Dinucci (UFS) por nos alertar para essas interpretações de Tieleman. 


\section{A Falta de Domínio de Si}

A falta de domínio de si (ảkpa oía) é tida como um dos mais clássicos problemas éticos da tradição filosófica. Tanto em Platão quanto em Aristóteles, a ausência de controle sobre os próprios atos foi entendida como uma fraqueza do indivíduo, como uma debilidade que impede tanto a felicidade quanto a autonomia. Nesse sentido, podemos também afirmar que a àkpaoía é uma espécie de incontinência que prejudica o de-

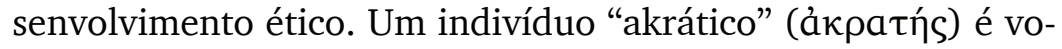
lúvel perante as circunstâncias, tem problemas de estabilização de humor e dificuldade em assegurar uma postura determinada. Além do mais, a falta de domínio de si também ocasiona a falta de determinação de si, uma vez que a potência nas decisões morais se torna menos confiável e menos digna de crédito.

Na tradição platônico-aristotélica, a ảkpaoía tem influência tanto sobre as potências irracionais quanto sobre as racionais, pois ela é pensada dentro de uma psicologia que analisa o comportamento por meio de partes distintas da alma (racional e irracional). Por isso, para combater o mal da falta de domínio de si, torna-se importante considerar métodos terapêuticos que lidem com esses dois aspectos. Por outro lado, na tradição estoica, o monismo psicológico característico da teoria difundida por Crisipo basicamente balizou a estrutura terapêutica da escola. Por considerar o juízo como algo inerente ao impulso, o estoicismo desenvolveu uma terapêutica racional que condiciona a àkpa áa às crenças falsas, ou seja, às opiniões equivocadas em nossos sistemas de valores (Boeri, 2007, p. 289-306). Sendo assim, a terapia estoica mostra-se filosófica por excelência, pois envolve as opiniões que temos das coisas, condicionando a retidão e a firmeza de caráter ao inevitável desenvolvimento do intelecto.

No entanto, como vimos anteriormente, durante o período do estoicismo médio ocorreram algumas inovações que ampliaram o escopo do debate da abordagem terapêutica. Dessa forma, a questão do domínio de si perante os arroubos passionais também ganhou outras conotações. Podemos identificar isso através das observações de Possidônio face às alterações de 
humor que ocorrem com o tempo. Para Possidônio, é possível que paixões diminuam com o tempo sem que necessariamente mudanças de opinião estejam envolvidas. O exemplo que ele utiliza para esclarecer sua teoria envolve a motivação do choro em momentos distintos. Conforme relata Galeno:

[Possidônio] censura com razão Crisipo quando este diz "pode ocorrer que, embora o impulso persista, o que lhe segue não o afete pelo fato de que haja uma disposição diferente que lhe sobrevenha". Nesse sentido, [Possidônio] sustenta que é inviável que o impulso esteja presente e que a atividade relacionada ao dito impulso seja impedida por alguma outra causa. Por isso, cada vez que Crisipo diz "assim, as pessoas deixam de chorar e, embora não queiram chorar, choram quando as coisas produzem representações dessemelhantes", nesse mesmo ponto Possidônio pergunta qual é a razão pela qual a maior parte das pessoas chora com frequência, ainda que não queriam, e são incapazes de controlar as lágrimas, e outros que querem seguir chorando, deixam de chorar. Obviamente, isso ocorre porque os movimentos passionais são tão violentos que não podem ser controlados pelo desejo racional, ou porque cessaram por completo a tal ponto que [tais movimentos] já não podem ser excitados pelo desejo racional. (SVF, III, 466)

Nesse caso, o choro não poderia ser atenuado por uma terapia racional, mas envolveria outras questões. Com isso, as paixões que impedem alguém de ter o domínio sobre si parecem não se relacionar somente a uma questão de ajuste de juízos. Consequentemente, Possidônio admite que é necessário avaliar o problema não só como uma questão racional, mas também como algo que envolve faculdades irracionais da alma. Por causa disso, ele afirmou que os males vêm do próprio indivíduo, pois não podem ocorrer somente pela avaliação racional de elementos externos que nos chegam via representações ( tão no indivíduo, sendo por isso que o mal ganha uma conotação interna (Edelstein; Kidd, 1999, fr. 163).

Por outro lado, como destacam Inwood (1985, p. 149) e Sorabji (2000, p. 32-33), parece que Crisipo tinha uma resposta a essa objeção de Possidônio: a diminuição ou o retorno do choro com o passar do tempo é algo que também envolve juízo, só que por meio de um segundo assentimento - agora no nível 
das paixões supervenientes (prazer e dor) - correspondendo à opinião de como é conveniente ( $\kappa a \theta \tilde{\eta} \kappa o v)$ agir no momento presente. Ou seja, é prestado um assentimento no momento presente de que é conveniente lamentar algo que já passou por um assentimento passional anteriormente. Sendo assim, apesar de se tratar de uma mesma manifestação corporal (choro), isso não quer dizer que tal se remete a um mesmo assentimento. Trata-se, portanto, de assentimentos diferentes. Dessa forma, a falta de domínio de si evidenciada pelo comportamento passional fica ainda atrelada a uma questão racional, uma vez que permanece vinculada às opiniões.

De acordo com Boeri (2007, p. 292-293), a tradição estoica basicamente assinala que a fraqueza da alma se manifesta na falta de firmeza nas opiniões (juízos), causada por uma

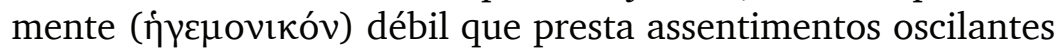
às representações. Nesse sentido, a fraqueza da alma não envolve nenhuma falta de esforço ou insuficiência de vontade, mas corresponde à carência de compreensão, à ignorância na

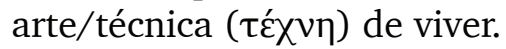

No estoicismo imperial, por meio dos textos que nos chegaram, essas questões não foram debatidas tão às claras, uma vez que a preocupação com os aspectos práticos foi mais evidenciada. Mesmo assim, Sêneca, em Da Tranquilidade da Alma (II, 3), afirma que a alma tomada por paixões é instável e volúvel, e isso ocorre porque a mente é tomada pela indecisão. Epicteto (Diatribes, II, 18, 23-26) e Marco Aurélio (Meditações, VII, 62) também permanecem fiéis à ortodoxia estoica, uma vez que eles entendem que a alma fraca é aquela que se precipita nos juízos, pois não é capaz de parar e analisar as representações de forma adequada.

\section{Responsabilidade}

Devido ao característico monismo psicológico estoico (não tomando aqui a polêmica com Possidônio), a consideração do impulso racional na teoria da ação é o que permite estabelecer o vínculo de responsabilidade. Dessa forma, os impul- 
sos passionais, por estarem ligados às opiniões, são entendidos como ações pelas quais somos responsáveis. A irracionalidade passional não é uma coisa pela qual podemos nos isentar da responsabilidade, uma vez que é fruto de nossos erros na avaliação de nossos valores. Por isso, talvez este seja um dos grandes propósitos do estoicismo: demonstrar que a busca pela boa vida, pela tranquilidade da alma (tranquillitas animi) e pelo sereno fluxo na vida (cúpoia) são tarefas que estão ao nosso alcance justamente por dependerem de nós, ou seja, por serem de nossa responsabilidade. Nesse sentido, não há motivos para retirar a própria responsabilidade dos atos errôneos, desmedidos: eles são resultados de uma determinada visão das coisas, de uma determinada forma de assentir. Muitas vezes esses atos podem passar despercebidos por já se tornarem habituais, sendo por isso mesmo difíceis de serem modificados. Justamente por isso, os estoicos assinalaram a importância de transformar a atividade de avaliação das opiniões em uma tarefa que faça parte do cotidiano daquele que quer uma vida melhor. Como diz Marco Aurélio: "hoje saí de todos os embaraços; ou melhor, expulsei todos os embaraços, pois não se achavam fora de mim, mas cá dentro, nas opiniões" (Meditações, VII, 62).

Da mesma forma que se pode assinalar que o distúrbio passional é um erro do qual somos responsáveis, pode-se também entender que a eliminação desses distúrbios (ảđá $\theta \varepsilon ı$ ) passa por uma correção na forma de pensar - que igualmente está sob nossa responsabilidade. Se, por um lado, o estoicismo pode parecer ser muito duro com aquele que erra, com aquele que está perturbado, por outro lado ele também ressalta o poder dessa mesma pessoa para resolver as suas dificuldades. Muitas vezes o problema também está nas opiniões que as pessoas têm de si mesmas. A confiança em si, na própria condição de ser um ser capaz de perceber a irracionalidade das paixões também cumpre um papel importante. Epicteto, por exemplo,

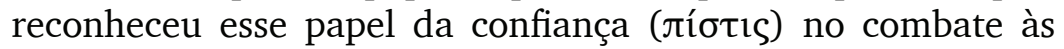
paixões, tanto que frequentemente chamava a atenção de seus alunos para que não subestimassem suas próprias capacidades enquanto seres racionais (Diatribes, I, 25, 4). 


\section{Primeiros Movimentos (Pré-paixões)}

Embora os estoicos tenham defendido a presença da racionalidade nos impulsos humanos, isso não necessariamente abrange todo e qualquer movimento. Nesse sentido, algumas reações podem não ser voluntárias, visto que não envolvem assentimento ${ }^{8}$. De acordo com o testemunho de Aulo Gélio, na obra Noites Áticas (XIX, 1, 14-21), em um dos livros perdidos das Diatribes de Epicteto estava escrito que mesmo um sábio pode ficar pálido perante uma situação de perigo ou até mesmo contrair-se. Tais reações são entendidas como movimentos rápidos e irrefletidos em que a atividade da razão encontra-se suspensa:

Um celebrado filósofo da doutrina estoica [...] retirou de sua bagagem de mão o quinto livro das Dialexeis do filósofo Epicteto, as quais, publicadas por Arriano, concordam indubitavelmente com os escritos de Zenão e Crisipo. Naquele livro escrito, é claro, em língua grega, lemos a seguinte sentença: As coisas vistas pelo espírito (as quais os filósofos chamam de phantasías), pelas quais a mente humana é atingida pela primeira imagem do que quer que penetre o espírito, não estão < sujeitas> nem à vontade nem ao arbítrio, apresentam-se por alguma força que lhes é própria, dando-se ao conhecimento dos homens; os assentimentos, porém, (os quais os filósofos chamam de sunkatatheseis), pelos quais as mesmas coisas são reconhecidas, são voluntários e feitos pelo arbítrio humano. Por essa razão, quando algum ruído terrível, < proveniente> ou do céu ou de um desabamento ou do anúncio de algum perigo de modo repentino e desconhecido ou de alguma outra coisa dessa maneira se faz, também o espírito do sábio necessariamente é movido, contrai-se e empalidece, não pela antecipação de algum mal, mas por certos movimentos rápidos e irrefletidos que suspendem o ofício da mente e da razão. Todavia, em seguida, esse mesmo sábio tás toiaútas phantasía (isto é: estas visões que atemorizam seu espírito) não aprova (isto é: ou sunkatatíthetai oude prosepidoxázei), mas as rejeita e repele, e não vê nelas o que quer que deva ser temido. E esses filósofos dizem diferir o espírito do sábio e do não-sábio no seguinte: que o não-sábio verdadeiramente pensa serem tais e quais as primei-

8

Usamos aqui o termo voluntário no sentido atribuído por Sêneca, em que o filósofo toma a voluntas por um assentimento, sendo diferente do sentido que o termo ganhou a partir da filosofia medieval. De acordo com Radice, Sêneca introduz por meio desse termo uma noção mais ampla que não estava presente na ortodoxia estoica (Radice, 2016, p. 218-223). Contudo, de acordo com Roberto H. Pich (2005, n. 198, p. 175-206 e 2005, n. 199, p. 139-157), o conceito de vontade, em um sentido mais próximo do que é compreendido atualmente, foi desenvolvido a partir da filosofia de Agostinho. 
ras coisas violentas e ásperas vistas pela sensação de seu espírito, como se com razão devessem ser temidas, e também com seu assentimento as aprova kai prosepidoxázei (pois os estoicos usam essa palavra quando falam sobre essas coisas); o sábio, porém, quando é movido breve e ligeiramente na cor e no vulto, ou sunkatatíthetai, mas mantém o status e o vigor das opiniões que sempre teve sobre as visões desse tipo, que não devem ser minimamente temidas, mas são aterrorizantes por sua falsa aparência e por seu oco espantalho. Essas coisas o filósofo Epicteto, a partir dos princípios dos estoicos, pensou e disse naquele já mencionado livro que lemos.

Nesses casos, como não envolvem assentimento a uma representação, esses movimentos rápidos e irrefletidos não são entendidos como passionais, de modo que podem acontecer até mesmo com um sábio. Com efeito, quando o sábio passa a refletir sobre a situação, ele não presta assentimento a uma representação que o deixará com medo, pois é justamente nesse momento que surgiria a paixão. Como o sábio tem opiniões em conformidade com a natureza, seus assentimentos não serão dados a representações falsas que o levem a crer que determinados perigos são males. Na verdade, o único mal reconhecido pelo sábio é aquele que depende única e exclusivamente dele, de seus assentimentos.

Da mesma forma que Epicteto, Sêneca também advertiu que movimentos preliminares (prévios aos assentimentos) não podem ser considerados paixões. Na obra Sobre a Ira, quando o filósofo reflete sobre o movimento do impulso raivoso, ele assinala que não basta somente um assentimento a uma representação de injúria para que o movimento passional ocorra. Além disso, é necessário prestar um segundo assentimento: o de que é apropriado vingar-se. De acordo com Sêneca:

Sem dúvida, o que move a ira é a ocorrência da ideia de uma injúria, mas indagamos se ela segue de imediato essa ideia e se ela se exterioriza sem que o consinta a alma ou se é movida com o assentimento desta. Aceitamos que a ira nada ousa por si mesma, mas, sim, com a aprovação da alma, pois tomar a ideia de uma injúria recebida e desejar sua vingança, e juntar uma coisa à outra - que não se deve sofrer agressão e que se deve obter vingança — , isso não é um impulso da alma suscitado sem a nossa vontade. O primeiro movimento é simples, o outro é complexo e compreende vários passos: perceber algo, indignar-se, condenar, cobrar vingança. Esses 
processos não podem ocorrer se a alma não deu assentimento aos estímulos pelos quais estava sendo atingida. 'Qual é a pertinência dessa questão?', perguntas. É para que saibamos o que é a ira, pois se ela nasce contra nossa vontade, nunca irá se curvar à razão. Todos os movimentos que não são feitos por nossa vontade são invencíveis e inevitáveis, como o arrepio ao sermos aspergidos de água fria, o asco a certos contatos; diante de notícias muito ruins, eriçam-se nossos pelos, alastra-se um rubor diante de palavras insolentes e segue-se uma vertigem quando se olha para precipícios. Ainda que nenhuma dessas sensações esteja em nosso poder, a razão não tem como persuadir a que não sejam produzidas. (De Ira, II, 1-2,1)

Esses movimentos preliminares, ou primeiros movimentos como foram denominados por Sêneca, foram posteriormen-

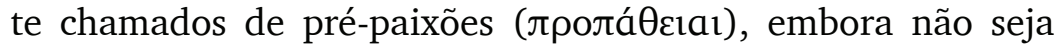
possível relacioná-los ao comportamento passional (Graver, 1999, p. 342). Dado que não se transita das pré-paixões às paixões, não se trata de uma relação sequencial no tempo. Como visto acima, a paixão precisa de assentimento para existir, precisa envolver uma opinião?

Embora Sêneca tenha sido o primeiro filósofo estoico de que se tem notícia a comentar sobre os primeiros movimentos, parece que essa ideia já estava presente no estoicismo ateniense. Como revela Margaret Graver (2007, p. 88), em seu livro Stoicism and Emotion, Fílon de Alexandria menciona a teoria dos primeiros movimentos, e seu conhecimento sobre isso só poderia ter sido subsidiado pela doutrina dos primeiros estoicos.

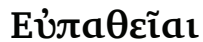

Um dos erros mais comuns ao interpretar o estoicismo é acreditar que eles pretendiam alcançar uma condição não-sentimental (levando em consideração o sentido moderno de apatia). No entanto, a ảлá $\theta \varepsilon ı$ a pretendida por eles se relaciona somente à ausência das emoções prejudiciais, viciosas. Por isso, é importante atentar para o fato de que as paixões não são todas

\footnotetext{
$9 \quad$ É por isso que somente os seres humanos podem ter paixões, pois são capazes de se posicionar racionalmente. Os demais animais, por não possuírem um raciocínio que leve em consideração o bem e o mal, por não terem uma

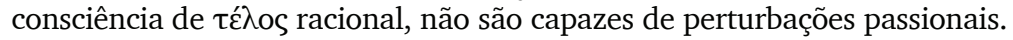


e quaisquer emoções, mas somente as irracionais. Sendo assim, como afirma Diógenes Laércio (VII, 116-117), no lugar das pai-

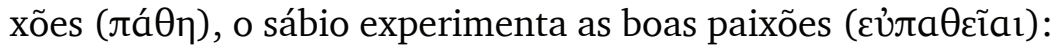

Também afirmam que as boas paixões são três: alegria, cautela e desejo racional (boa vontade). Dizem que a alegria se opõe ao prazer, pois é uma exaltação racional, e que a cautela se opõe ao medo, pois evita racionalmente o perigo. Logo, o sábio de nenhum modo terá medo,

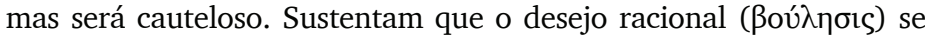

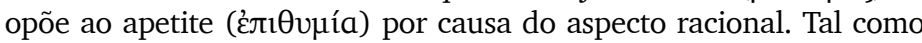
algumas [paixões] se subordinam às paixões primárias, do mesmo modo acontece [com as boas paixões] que se subordinam às boas paixões primárias: ao desejo racional [se subordinam] a benevolência, a bondade, o afeto, o carinho; à cautela [se subordinam] o pudor, a pureza; à alegria [se subordinam] o enlevo, o regozijo, a serenidade.

Ao afirmar a existência das boas paixões, os estoicos podem assim mostrar que uma vida orientada pela razão não elimina os aspectos emocionais da vida humana. Nesse sentido, o sábio estoico também tem emoções, é alegre, cauteloso e seu desejo é arrazoado. Por isso, o caminho para a sabedoria é, ao mesmo tempo, o caminho para as boas paixões, para a boa vida emocional. Nesse sentido, como afirmam Boeri e Salles (2014, p. 597), "a eliminação das paixões deve apontar para seu tratamento através da filosofia para transformar as paixões em 'boas paixões"'. A terapia estoica, portanto, visa a transformação emocional do indivíduo, de forma a fazer com que as paixões que prejudicam e perturbam deem lugar às boas paixões que beneficiam e regozijam. Ao efetuar esse caminho, o indivíduo que progride nos ensinamentos estoicos vai notando que os impulsos passionais vão aos poucos se arrefecendo, uma vez que passa a deixar de julgar os indiferentes como fins em si mesmos e começa a atuar de forma "eupática" por meio da virtude.

Por fim, com o objetivo de melhor ilustrar a abordagem

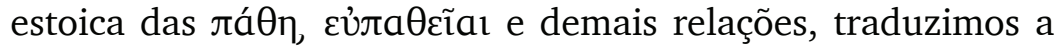
seguir um esquema elaborado por Strange (2004. p. 34) no capítulo On the Voluntariness of the Passion do livro Stoicism: Traditions and Transformations: 


\begin{tabular}{|c|c|c|c|}
\hline \multicolumn{2}{|c|}{$\begin{array}{l}\text { ő } \rho \xi \xi \varsigma \\
\text { Desejo/busca por um bem futu- } \\
\text { ro aparente }\end{array}$} & \multicolumn{2}{|c|}{ 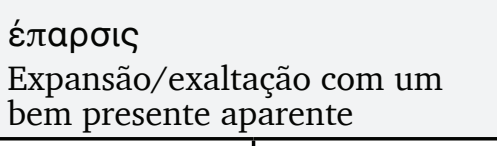 } \\
\hline $\begin{array}{l}\text { 1. غ̇ंıӨupía } \\
\text { Apetite (por } \\
\text { um bem } \\
\text { futuro apenas } \\
\text { aparente) }\end{array}$ & 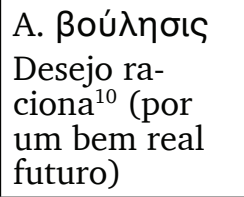 & $\begin{array}{l}\text { 2. ๆंठoví } \\
\text { Prazer (com } \\
\text { um bem pre- } \\
\text { sente apenas } \\
\text { aparente) }\end{array}$ & $\begin{array}{l}\text { B. xapá } \\
\text { Alegria (com } \\
\text { um bem real } \\
\text { presente) }\end{array}$ \\
\hline \multicolumn{2}{|c|}{$\begin{array}{l}\text { ह̌ } \kappa \kappa \lambda \imath \sigma ı \varsigma \\
\text { Aversão a um mal futuro } \\
\text { aparente }\end{array}$} & \multicolumn{2}{|c|}{ 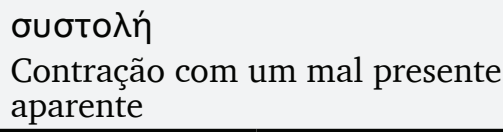 } \\
\hline $\begin{array}{l}\text { 3. Фóßos } \\
\text { Medo (de um } \\
\text { mal futu- } \\
\text { ro apenas } \\
\text { aparente) }\end{array}$ & 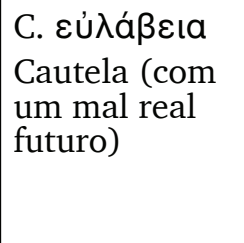 & $\begin{array}{l}\text { 4. } \lambda u ́ \text { un } \\
\text { Dor/ } \\
\text { aflição (por } \\
\text { um mal pre- } \\
\text { sente apenas } \\
\text { aparente) }\end{array}$ & 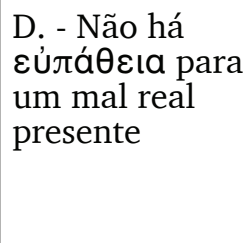 \\
\hline
\end{tabular}

\section{Considerações finais}

Para os estoicos, as paixões de maneira nenhuma se desvinculam da racionalidade. Elas só podem ser chamadas de irracionais na medida em que são frutos do mau uso da razão, e não da ausência desta. Diferentemente dos animais, os seres humanos desenvolvem a racionalidade durante a infância, fazendo com que, na idade adulta, a razão se torne a artesã dos impulsos, capaz de direcioná-los intencionalmente. Nesse sentido, os impulsos passionais ocorrem em função de crenças errôneas que assimilam como bens coisas que não deveriam ser valoradas dessa maneira. Para os estoicos, os bens são as virtudes, os impulsos virtuosos que se alinham adequadamente às circunstâncias, explicitando assim a boa e sábia relação com aquilo que ocorre.

As paixões não devem ser entendidas como efeitos que envolvem paralelamente a nossa vida psíquica, uma vez que elas mesmas estão implicadas nas ações sob a forma de ações de certa maneira. Pode-se, por exemplo, assistir uma palestra com boa

\footnotetext{
$10 \quad$ Na tradução de Strange, "wish".
} 
vontade ou com raiva, inveja, etc. Isso vai depender das opiniões que estão envolvidas na ação de assistir a palestra.

Por outro lado, é importante destacar que algumas reações rápidas e involuntárias não podem ser tomadas como paixões, como, por exemplo, empalidecer ou contrair-se na ocasião de um perigo imediato. Tais reações são naturais e não denotam medo, uma vez que somente podem ser chamadas de paixões as ações que passam pelo crivo do assentimento. Esse exemplo mostra como as paixões só podem ser tomadas como tais a partir da elaboração de uma opinião sobre os fatos.

Por fim, ao contrário do que se pode ingenuamente pensar, o estoicismo não é uma doutrina que defende a apatia no moderno sentido do termo. A ả̇áӨcıa defendida pelos estoicos não se refere a uma ausência de estados emocionais, não é viver como uma estátua, é antes viver sem paixões, mas não sem as

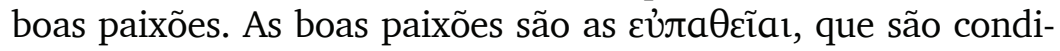
zentes com uma vida sábia, pois são impulsos que estão em compatibilidade com a natureza, associados a uma vida que flui harmonicamente. Nesse sentido, pode-se dizer que a transformação das paixões em boas paixões é o objetivo da terapêutica estoica.

\section{Referências}

ANNAS, J. The morality of happiness. New York: Oxford University Press, 1993.

ARISTÓTELES. Ética a Nicômaco. Tradução do grego de António de Castro Caiero. São Paulo: Atlas, 2009.

ARNIM, H von. Stoicorum Veterum Fragmenta. Leipzig: Teubner, 19031905, v. 1-3, 1924, v. 4. (Índices por M. Adler).

AULO GÉLIO. Noites Áticas. Trad. José Rodrigues Seabra Filho. Londrina: EDUEL, 2010.

BOERI, M. D. Apariencia y Realidad en el Pensamiento Griego: investigaciones sobre aspectos epistemológicos, éticos y de teoría de la acción en algunas teorías de la Antigüedad. Buenos Aires: Colihue, 2007.

BOERI, M. D.; SALLES, R. Los Filósofos Estoicos: Ontología, Lógica, Física y Ética. Sankt Agustin: Academia Verlag, 2014.

BRENNAN, T. A Vida Estoica: emoções, obrigações, destino. Trad. Marcelo Consentino, São Paulo: Loyola, 2010. 
CÍCERO. Textos Filosóficos. Trad. J. A. Segurado e Campos. Lisboa: Fundação Calouste Gulbenkian, 2012.

CICERÓN. Disputaciones Tusculanas. Introducción, traducción y notas de Alberto M. González. Madrid: Gredos, 2005.

COOPER, J. Reason and Emotion. Essays on Ancient Moral Psycology and Ethical Theory. Princeton: Princeton University Press, 1999.

CRISIPO DE SOLOS. Testimonios y Fragmentos. Trad. de F Javier Campos Daroca e Mariano Nava Contreras. Madrid: Editorial Gredos, 2006, v. 1 e 2.

DELEUZE, G. Lógica do sentido. Trad. de Luiz Roberto Salinas Fortes. 5 ed. São Paulo: Perspectiva, 2011.

DIÔGENES LAÊRTIOS. Vidas e doutrinas dos filósofos ilustres. Tradução de Mário da Gama. Brasília: Editora Universidade de Brasília, 2008.

EDELSTEIN, L.; KIDD, I. G. (ed.). Posidonius: The translation of the fragments. Cambridge: Cambridge, 1999, v. 3.

EPICTETO. Fragmentos e Testemunhos. Trad. Aldo Dinucci e Alfredo Julien, São Cristóvão: EdiUFS, 2008.

EPICTETO. Disertaciones por Arriano. Tradução de Paloma Ortiz García. Madrid: Editorial Gredos, 1993.

EPICTETUS. The Discourses as reported by Arrian, The Manual, and Fragments. Tradução de W. A. Oldfather. Londres: Heinemann, 1961. v. 1.

EPICTETUS. The Discourses as reported by Arrian, The Manual, and Fragments. Tradução de W. A. Oldfather. Londres: Heinemann, 1952. v. 2.

EPICURO - LUCRÉCIO - CÍCERO - SÊNECA - MARCO AURÉLIO. 3 ed. São Paulo: Abril Cultural, 1985. Coleção Os Pensadores.

GRAVER, M. Philo of Alexandria and the Origins of the Stoic ПролáӨcıal. Phronesis, v. 44, n. 4, 1999, p. 300-325.

GRAVER, M. Stoicism and Emotion. University of Chicago Press, 2007. HUSSON, S. O conveniente, as paixões, o sábio e a cidade, In: GOURINAT, J.-B; BARNES, J. Ler os estoicos. Tradução de Paula S. R. C. Silva. São Paulo: Edições Loyola, 2013.

INWOOD, B. Ethics and Human Action in Early Stoicism. Oxford: Oxford University Press, 1985.

SEDLEY, D. A Escola de Zenon a Ário Dídimo, In: INWOOD, Brad (Org.). Os estoicos. Tradução de Paulo Fernando Tadeu Ferreira e Raul Fiker. São Paulo: Odysseus, 2006.

KANT, I. Metafísica dos Costumes. Trad. Clélia Aparecida Martins, Bruno Nadai, Diego Kosbiau e Monique Hulshof. - Petrópolis, RJ: Vozes; Bragança Paulista, SP: Editora Universitária São Francisco, 2013.

KIDD, I. G. Posidonius: The Commentary (ii). Cambridge: Cambridge, 2004, v. 2. 
LONG. A A. La filosofía helenística: estoicos, epicúreos, escépticos. Trad. P. Jordán de Urries. Madrid: Alianza, 1984.

PICH, R. H. Agostinho e a 'descoberta' da vontade: primeiro estudo. Veritas. Porto Alegre, v. 50, n. 198, 2005, p. 175-206.

PICH, R. H. Agostinho e a "descoberta" da vontade: primeiro estudo (continuação e fim). Veritas. Porto Alegre, v. 50, n. 199, 2005, p. 139-157.

PLATÃO. A República. Tradução e organização de J. Guinsburg. São Paulo: Perspectiva, 2012.

RADICE, R. Estoicismo. Trad. Alessandra Siedschlag. São Paulo: Ideias \& Letras, 2016.

RIST, J. M. La Filosofía Estoica. Trad. David Casacuberta. Barcelona: Editorial Crítica, 1995.

SÉNECA. Cartas a Lucilio. Tradução de Vicente López Soto. 4 ed. Barcelona: Editorial Juventud, 2012.

SÊNECA. Sobre a Ira; Sobre a Tranquilidad da alma. Trad. José Eduardo S. Lohner, São Paulo: Penguin, 2014.

SORABJI, R. Emotion and Peace of Mind: From Stoic Agitation to Christian Temptation. New York: Oxford, 2000.

STRANGE, S. K. On the Voluntariness of the Passion, In: STRANGE, S.; ZUPKO, J. (ed.). Stoicism: Traditions and Transformations. Cambridge: Cambridge University Press, 2004.

TIELEMAN, T. Chrysippus' On affections: reconstruction and interpretation. Leinden: Brill, 2003. 